\title{
GENDER STEREOTYPING AND RETRO- SEXISM IN ADVERTISING DISCOURSE FROM A POSTFEMINIST PERSPECTIVE
}

\section{ESTEREOTIPOS DE GÉNERO Y RETROSEXISMO EN EL DICURSO PUBLICITARIO DESDE UNA PERSPECTIVA POSTFEMINISTA}

Antonia MONTES

Author / Autora:

Antonia Montes

Universidad de Alicante

Alicante, Spain

antonia.montes@ua.es

https://orcid.org/0000-0001-7933-5775

Submitted / Recibido: 4/12/2020

Accepted / Aceptado: 13/04/2021

To cite this article / Para citar este artículo: Montes, A. (2021). Gender stereotyping and retro-sexism in advertising discourse from a postfeminist perspective. Feminismo/s, 38, 177-202. Women, Sexual Identity and Language [Monographic dossier]. I. Balteiro (Coord.). https://doi.org/10.14198/ fem.2021.38.07

\section{Licence / Licencia:}

This work is licensed under a Creative Commons Attribution 4.0 International.

\section{(c) (1)}

(C) Antonia Montes

\begin{abstract}
Negative female stereotypes and the portrayal of women in traditional and non-agentive social roles prevail in advertising. Advertisers believe that it is an effective advertising strategy to misuse postfeminist standpoints, stressing liberated womanhood and constructing a universe where women have gained it all and men have to reconquer their lost ground. This article analyses the appropriation of postfeminist discourse with the aim of showing how negative and even demeaning female stereotypes and clichés are represented, and by doing so, how a retro-sexist imagery is constructed within the advertising discourse. Undertaking a case study analysis of an advertising campaign of the brand IWC, a luxury brand for watches, and applying a feminist critical discourse perspective (Lazar, 2005, 2007), which shows the gender asymmetries in discourse, it is argued that advertising perpetuates misbeliefs about women's roles in society and reinforces demeaning female stereotypes in the collective imaginary about the understanding of gender equality.
\end{abstract}


Keywords: advertising discourse; postfeminism; gender stereotypes; retro-sexism; gender asymmetry; gender equality.

\section{Resumen}

En la publicidad prevalecen los estereotipos femeninos negativos y la representación de las mujeres en roles sociales tradicionales, ligados a actividades y ocupaciones domésticas. Los anunciantes creen que la utilización de los planteamientos posfeministas para sus propios fines es una estrategia publicitaria eficaz. Este artículo analiza la apropiación del discurso posfeminista con el objetivo de mostrar cómo se representan los estereotipos y clichés femeninos negativos e incluso degradantes. También se examina cómo se construye un imaginario retro-sexista en el discurso de la publicidad. Se realiza, desde una perspectiva del discurso crítico feminista (Lazar, 2005, 2007), un estudio de caso de la marca de relojes de lujo IWC. Se concluye que la publicidad perpetúa las visiones erróneas sobre el rol de la mujer en la sociedad y refuerza los estereotipos femeninos negativos y degradantes mediante la construcción de un universo retro-sexista en el imaginario colectivo y dificulta el progreso hacia la igualdad de género.

Palabras clave: discurso publicitario; posfeminismo; estereotipos de géneros; retrosexismo; igualdad de género.

\section{INTRODUCTION}

«Equality of the sexes has to stop somewhere». This is one of a series of claims that make up the advertising campaign of the Swiss watch brand IWC, launched in the early 2000s. It is worth analysing this peculiar advertising discourse taking into account postfeminist standpoints to examine the representation of female stereotypes and the strategies applied in the creation of a retro-sexist imagery.

Advertising as part of popular culture is a central means of social communication, and as such it tells stories about our culture, and these stories are often gendered in their structure and content (Arend, 2014). Thus, it strongly influences the collective imaginary of gender perception, as advertising creates, includes and reinforces social trends. In particular, the stereotypical portrayal of women and retro-sexism in advertising, which is the article's focus, is analysed and criticised by feminist scholars of various disciplines such as marketing and business, cultural studies, semiotics and linguistics, 
among others. Feminist studies with a linguistic and discursive point of view, as for example Tannen (1995) for conversational linguistics, Mills (1995) for stylistic issues and feminist critical discourse analysis (Lazar, 2005, 2007), offer a range of tools to understand and challenge «the complex working of power and ideology in discourse in sustaining a (hierarchically) gendered social order» (Lazar, 2005, p.1).

In fact, gender stereotypes and clichés about gender roles prevail in advertising. Some studies (Furnham \& Paltzer, 2010; Grau \& Zotos, 2016) show that advertising still conveys negative gender stereotypes and presents gender roles in unequal situations, even in egalitarian geographical areas such as Europe or the USA, where gender equality and equity has become a social demand. Some shifts in the portrayal of women and men can be observed in campaigns that represent women in agentive roles, meaning in a non-traditional professional setting, or depicting women showing their real bodies; men are depicted in softer and caring roles, as fathers acting with their children. As reported in more recent research (Zawisza, 2019), advertising profits from portraying women in a traditional, caring role or in a sexist manner, as housewives or sex objects, despite the many social changes for women in the last decades. Feminists are constantly fighting to break existing patriarchal power relations that reign in the public and private spheres. Some advertisers believe that it is an effective advertising strategy to mis-use feminist standpoints in advertising discourse to convey their advertising message. Sometimes, advertisements not only transmit destructive messages about women, but they also ridicule feminist gains in favour of gender equality in society. Such kind of advertising perpetuates misbeliefs about women's roles in society and reinforces demeaning female stereotypes in the collective imaginary about the understanding of gender equality.

The purpose of this article is the study of a retro-sexist advertising discourse, constructed by misusing feminist gains and progress towards gender equality. Retro-sexism is understood as the portrayal of a female-dominated society that generates powerful sexist feelings (Williamson, 2003). It is argued that the act of stereotyping the female role in society reinforces retro-sexist stereotypes in the collective imagery about femininities. Specifically, this study focuses on the question of how negative and even demeaning female

Feminismo/s 38, July 2021, 177-202 
stereotypes and clichés are represented within advertising discourse. To answer this question, a content analysis of the advertising campaign of the Swiss watch brand IWC (IWC Homepage) is carried out. This brand proves to be very suitable for a case study analysis, as in the 2000s IWC launched, in German and less in English, a provocative advertising campaign in the German-speaking European market, in which the advertising discourse was based on female stereotypes and clichés that were partially demeaning, thus, conveying a non-realistic female image and reinforcing a retro-sexist imagery. The IWC advertising campaign is about men's watches, and it consists of one single slogan and numerous claims. The slogan in the English version 'Since 1868. And as long as there are men' and in the German version 'Seit 1968. Und solange es Männer gibt' is continuous throughout the whole campaign and can be found in all advertisements. The claims change in each advertisement and they constantly reinforce masculinity at the expense of undermining femininity. By doing this, a retro-sexist imagery is transmitted, where feminist gains in favour of gender equality are pushed aside and sexist thinking is perfectly acceptable. For this study, a sample of 78 advertisements were selected, found on the internet (IWC-Werbung wirkt, 2015). The advertisements chosen in the sample and object of analysis were designed by the Austrian advertising agency 'Wirz Werbung' and were launched in the form of posters from 1999 until 2005. In order to examine this cutting-edge gendered advertising discourse, a discourse analysis approach is formulated from a postfeminist perspective, where the representation of gender stereotypes and the construction of a retro-sexist imagery is examined in a qualitative way. For our analytical procedure, the approach 'Feminist Critical Discourse Analysis (FCDA)', mainly concerned with «critiquing discourses which sustain a patriarchal social order» (Lazar, 2005, p. 5), provides a useful framework in which to examine how women are addressed and represented in gendered advertising discourse.

With the aim of addressing the above-mentioned proposals, this paper takes an interdisciplinary approach, combining marketing and advertising findings with studies on postfeminism and discourse analysis. Hence, it is divided into two main parts. In the first part, with a theoretical emphasis, a literature review of feminism and postfeminism in marketing and advertising discourse is presented, which outlines the relationship between the

Feminismo/s 38, July 2021, 177-202 
different feminist waves and marketing/advertising. Although postfeminism has adopted a more relaxed view on the marketplace, forces have emerged that exhibit, to a certain degree, retro-sexism. The first part ends with an overview of gender roles and stereotypes and how they are depicted by advertising. The second part of the article offers a detailed analysis of the case study of the Swiss watch brand IWC, examining how a retro-sexist imagery is constructed and how the gender stereotypes are represented within a self-critical postfeminist discourse analysis following the feminist perspective to critical discourse analysis (Lazar, 2005, 2007). The paper concludes that this type of gendered advertising discourse, by employing a strategy that conveys demeaning messages about the physical appearance and social status of women, and simultaneously constructs a retro-sexist imagery, damages, to a great extent, the evolution towards gender equality and, therefore, social justice. To begin with, the notions of feminism and postfeminism are described in relation to marketing and advertising. Also, the meaning of retro-sexism is explained.

\section{FEMINISM, POSTFEMINISM AND RETRO-SEXISM IN MARKETING AND ADVERTISING}

There is an ongoing debate between marketing and feminism about whether the marketplace means exploitation or empowerment for women, in other words, if the market opposes or assists the feminist cause (Catterall et al., 2005; Maclaran, 2012; Rome et al., 2019; Scott, 2005). Feminist attitudes towards the marketplace are strongly influenced by the different waves feminism has gone through (Maclaran, 2012; Rome et al., 2019).

From Maclaran's historical overview (2012), which describes the relationship between feminism and marketing, it can be asserted that first wave feminism saw an improvement in the social and political position of women throughout the marketplace, where department stores were places to socialize with each other and not be under men's observation. Women became consumers, with an expertise that was legitimized in the public sphere. Department stores promised fashion for all, so they became a place where a certain social equality reigned (Maclaran, 2012, p. 463). The feminist movement sought policy reforms and the right of women to participate

Feminismo/s 38, July 2021, 177-202 
in the political system. Suffragettes discovered the marketplace to convey their message. Some of them used it for their own benefit to improve their celebrity status by e.g. participating in advertising campaigns as Elizabeth Cady Stanton did (Rome et al., 2019, p. 253). Hence, the first wave feminism embraced the marketplace for its cause and contributed to improve the social and political position of women.

In the second wave of feminism, the marketplace was seen as a field of oppression for women, and advertising contributed considerably to perpetuating negative stereotypes and pushing them into a housekeeping role in a patriarchal society or in an exploited position as sex objects (Maclaran, 2012, p. 465). In the 60s, second wave feminists distanced themselves from consumerism, attacking mass media and blaming the marketplace of imposing a patriarchal agenda (Rome et al., 2019, p. 253). Feminists like Betty Friedan accused advertising of perpetuating negative stereotypes of women and emphasizing their housekeeping role and other feminine duties in order to ensure their continued 'enslavement to consumerism' (Maclaran, 2012, p. 465). A critical approach to the marketplace persisted into the 90 s. Feminism was against marketing and consumerism, «promoting a natural, authentic self that could be realized through various styles that were both anti-fashion and anti-capitalist» (Catterall et al., 2005, p. 494). Advertisers started to incorporate feminist ideas into the advertising messages in order to meet the consumer expectations of a majority of women.

However, the third wave sees the market as a place where women can express their femininity through empowerment and purchase power. Catterall et al. (2005) states a celebratory turn, in which gender is regarded as another ludic element of a fluid and mutable self. The construction of femininities intersecting with other social variables such as race, ethnicity or social classes is the core theme of third wave feminism, looking deeply into the production of a multiplicity of potential feminine subjectivities. The relationship between marketing and feminism has undergone a reconciliation process that links empowerment to sexual expressiveness and purchasing power.

The term 'postfeminism' is sometimes equated with third wave feminism when including intersectional subjectivities (Rome et al., 2019, p. 267). But it often suggests the absence of a need for feminism, as gender equality has 
been achieved (McRobbie, 2009). Regarded as «a media-friendly, consumer-oriented discourse» (Lazar, 2006, p. 505), it assures that women can 'have it all' and are able to achieve positions of power. Consumption becomes an integral part of postfeminism as it offers women independence, agency and confidence. Advertisers appropriate feminist values as freedom, choice and equal opportunities, offering the fulfilment of a certain femininity by consumption. Catterall et al. (2005) speak about a 'postmodern paralysis', understanding that the market creates the ideal of liberated womanhood that quells any activism and subversion from outside the market, as «after all, if the market is now perceived as a site for rebellion what is the point in trying to act from outside?» (p.490).

As has been stated, postfeminism appropriates certain feminist notions of empowerment and emancipation, but it is also characterized by the rejection of the most radical aspects such as the systematic oppression in a patriarchal-dominated society. There is a dualism observable between feminism and post feminism (Lewis et al., 2017, p. 214). On the one hand, feminist values such as choice, equality of opportunities and agentic self-determination are totally acceptable, on the other hand, re-articulation of traditional expectations and traditional gender stereotypes about motherhood, beauty and female sexuality are also part of the postfeminist discourse. McRobbie (2009) coined the expression 'double entanglement', referring to a sort of coexistence or take-up of feminist principles alongside the repudiation of feminist action and a process of re-traditionalization.

In line with this process and as a backlash against the postfeminist assumption that 'women can have it all' goes the term 'retro-sexism', coined by Williamson (2003), which can be defined in an advertising context as the "communication of culturally sanctioned aspects of femininity related to notions of dependency, attractiveness, and adherence to household tasks» (Plakoyiannaki \& Zotos, 2009, p. 1412). It is a social phenomenon that the portrayal of a female-dominated society generates powerful sexist feelings. Williamson (2003) explains the origin of retro-sexist imagery, starting when feminism and sexism became out-of-date in the 1990s, and issues of sexuality rather than gender became the focus of cultural debate. Retro-sexism evokes an imagery where it seems perfectly right and socially acceptable to think of women in domestic roles as serving their family and at the same time 
being sex objects to amuse men, as if the feminist era and all the feminist gains had never existed. On the other hand, the sexual representations of women in retro-sexist imagery shows an assimilation of feminist criticism against sexist advertising to promote 'commercial femininities' in the service of commodity consumption (Lazar, 2006).

As described, in postfeminist media and advertising discourse, women are regarded as empowered consumers. Postfeminist discourses of choice, empowerment and (sexual) pleasure shape increasingly femininities with an emphasis on consumerism (Gill \& Arthurs, 2006). As consumption in a neoliberal economic order has changed the understanding of femininity, Lazar (2006) coins the term 'Power Femininity' to denote «an empowered and/or powerful feminine identity» (p. 505). More specifically, it is a global discourse with postfeminist ideas about the end of the feminist struggle, the achievement of full equality for all women and the desire for self-aestheticization. Lazar (2006), in her study of advertisements of beauty products establishes four types of Power Femininity: empowered beauty, knowledge of power, agentive power and sexual power. The author comes to the conclusion that advertising constructs a sort of globalized consumer sisterhood based on erasure, accommodation and bridging the gap between women from a range of cultures and geographical areas (Lazar, 2006, p. 513/514).

Scholars researching on postfeminism (Gill \& Arthurs, 2006; Gill, 2016) observe that the consumerist discourse appropriates feminist arguments that promise women they can gain the desired empowerment and freedom to choose the femininity they want by consuming a certain brand and product. But this is illusory, as the products themselves impose a certain femininity and by doing so, they reinforce standards of femininities. This commodification creates standards of femininities and, thus, gender identity becomes a construction of consumerism. Undoubtedly, marketing practices and strategies shape gender identities and social roles that continue to perpetuate gender inequality.

\section{GENDER ROLES AND GENDER STEREOTYPING IN ADVERTISING}

Advertising has a great impact on postmodern thinking of gender, as «consumers are seen as producers of symbolic meanings that attach to goods and 
services» (Catterall et al., 2005, p. 490). Gender stereotypes of women are a common feature used in advertising strategies. The social roles in which women and men are presented do not always match up in real life. There is often an unequal depiction of both genders, causing, in most cases, a disadvantage for women and, hence, reinforcing stereotypes about female roles in society. There is a consensus that «advertising contributes to gender inequality by promoting sexism and distorted body image symbols as valid and acceptable» (Grau \& Zotos, 2016, p. 762).

Gender stereotypes, based on a binary assumption, are centred on a «belief that certain attributes differentiate men and women» (Eisend, 2019). This means that stereotypes convey certain images of how women and men should be, look like, behave and act. Eisend (2019) establishes four categories of gender attributes: personality traits, physical characteristics, role behaviours, and occupational status. Stereotyping in advertising occurs when gender is not depicted equally according to the gender roles expectations in a society.

Plakoyiannaki \& Zotos (2009) establish four categories of female role stereotypes in advertising. The first one is the depiction of women in decorative roles. Female stereotypes that express concerns about their physical appearance and beauty, as well as the portrayal of women as sexual objects, fall into this category. The second category is the most widespread. On the one hand, women are portrayed in traditional roles, which means that they are dependent on male protection and in need of reassurance. On the other hand, they are shown as housewives, because a woman's place is in the domestic sphere and her primary role is to be a good housewife for her children and husband. In this category, women are primarily concerned with performing tasks of housekeeping. As regards the third category, the depiction of women in non-traditional and agentive roles shows them engaged in non-traditional activities outside home, career-oriented in a professional occupation or as a voice of authority, where women are experts on certain topics. In the last category, women are shown in a neutral role, as equal to men. Grau \& Zotos (2016) have shown that women are presented mainly in more decorative roles, concerned about their body and beauty, and family oriented roles, but less in professional roles. Men instead are typically depicted as more independent, authoritarian and in a professional setting. In stereotypical 
male portrayal, age and physical appearance are almost irrelevant. But there is a tendency to portray men in less agentive attitudes and more engaged in housework and as carers. Female portrayal in advertising has also undergone changes. There is a new wave of advertising campaigns aiming at empowering women through pro-female messages and imagery, labeled 'femvertising'. The aim of these advertisements is to «challenge female stereotypes and the social stigmas women face» (Windels et al., 2019, p. 19).

When assessing the effectiveness of stereotyping in advertising, it can generally be stated that positive effects are reached when consumers perceive that gender portrayals are congruent with their social vision about genders and these match their gender-role expectations (Eisend, 2019, p. 73). Depictions that are to some extent counter stereotypical can also lead to favourable effects. However, research reports greater effectiveness of female portrayals in traditional roles compared to presenting women in agentic roles. Male portrayal, on the contrary, has undergone slight changes in favour of the father figure and family carer. Nevertheless, marketers are more likely to choose traditional gender role portrayals, without taking the social changes genders have undergone into account. The social effects of gender stereotyping in advertising for both genders can be dramatic. Research in this field (Plakoyiannaki \& Zotos, 2009, p. 1429) has shown that women suffer from negative self-perception and low self-esteem by constantly being shown in a decorative role, low body satisfaction by presenting unreachable body shapes, and, finally, a reduced professional performance and achievement as a result of being portrayed to a greater extent in traditional roles than in non-traditional and agentive roles. In the same way, portraying men from a traditional masculine ideal perspective, neglecting new attributes men have gained in social change, can lead to male anxiety and loss of self-confidence (Eisend, 2019, p. 76).

The question arises why advertisers do not adjust advertising messages to the deep social changes both genders, but especially women, have undergone. And furthermore, why advertising is not able to use its power to contribute to social change by favouring gender equality. There are two opposed standpoints. The first one is based on the mirror metaphor. Advertising, like a mirror, shows the conventions and desires of society by using existing values instead of altering them. In this view, advertising follows the 
dominant concepts about gender roles. Secondly, the mold argument conveys that consumers create a reality according to the advertised images. By doing so, they incorporate stereotypes presented by the media into their system of values and beliefs.

Advertising campaigns create gender identity, based on their images, the stereotyped iconography of masculinity and femininity (Grau \& Zotos, 2016, p. 763). Advertising according to the 'mold' vision could be the driving power of change in gender perception, as there is clear evidence that repeated exposure to gender portrayals presented in advertising leads to a social transformation in gender-related values and behaviours. In fact, advertising has a great power in working towards gender equality replacing traditional gender role stereotypes with non-traditional, that correspond to real social gender roles in contemporary society.

\section{STEREOTYPICAL RETRO-SEXIST DISCOURSE PRAXIS: THE CASE STUDY OF IWC}

In the advertising universe watches show more than time and especially when belonging to a high-prized segment, watches stand for luxury and are a status symbol. The brand assigns the consumer a specific, attractive personality. Generally, brands of watches emphasize the quality and the craftsmanship in producing watches. Built around the values of competition, eagerness, achievements of goals and success, an attractive world is created. Often, outstanding people are portrayed in their activities and professions, such as actors/actresses, sportsmen/sportswomen, scientists, artists, etc. For watch brands, gender is an important issue, and some brands, such as Rolex, tend to equalize female and male performance in advertising because the branding of watches is never gender-neutral (Kreienkamp, 2007, p. 91).

\subsection{About the advertising campaign}

IWC, funded in Schaffhausen (Switzerland) in 1868 by the American Florentine Ariosto Jones, is a traditional Swiss brand, which produces high quality and high-priced watches especially for men, but also for women, considering that women have become a popular target group of about $20 \%$ purchase capacity (Weber, 2002). In the first decade of the 2000s and for 
six years, around 1000 advertising posters (Wirz ohne IWC Uhren, 2005) mainly in German and less in English were designed by the advertising agency 'Wirz Werbung'. The advertising campaign is striking because of the slogan 'Since 1868. And as long as there are men', and very provocative claims, such as for example: 'Typical male characteristic. / Almost as complicated as a woman. Except it's on time. / How faithful are men? We've never known one to leave his IWC'.

As a brand, IWC has undergone a radical change in its advertising campaign, and instead of promoting the watch itself or famous people that wear it, as other brands do, it launched a campaign that was acclaimed in the advertising sector as being original, humorous, ironic and trenchant, with the potential of a high image formation for the brand, as the outcome is a community feeling among those understanding this kind of humour (Wirz ohne IWC, 2005). Women journalists instead called it a «testosterone-driven advertising campaign» (Lüchinger, 2005) or a campaign «for the last Mohicans» (Weber, 2002). The Swiss magazine 'Werbewoche', a specialised magazine in advertising, characterised it as a campaign that conveys a «Machismo-Lebensgefühl» [translated: feeling for life based on machismo] (Uhrenwerbung im Stillstand, 2001).

As the advertising campaign was very successful in German-speaking Europe, it has been argued that a retro-sexist campaign such as the IWC can only be successful in societies which have undergone feminism, postfeminism and all the fallacies and backlashes (Weber, 2002). However the advertisers are aware that this type of campaign would not work in Japan or in the United States (IWC wechselt zu JvM/Alster, 2005). In terms of feminist critique, in our vision, the reason why such a campaign could be successful might be explained by a prevailing gender ideology, understood as a structure based on a hierarchical relation of domination and subordination with the interest in maintaining unequal and hegemonic power relations and dominance, «in that it often does not appear as domination at all; instead it seems largely consensual and acceptable to most in the community» (Lazar, 2005, p. 7). It is this taken-for-grantedness that contributes to the unawareness of power differential and gender inequality. 


\subsection{Analytical procedure}

In order to shed light into the cutting-edge discourse praxis of the IWC advertising campaign, the data of this study comprises 78 advertisements that refer to gender conflict, gender stereotypes and retro-sexist allusions. All the advertisements in our corpus were designed by the advertising agency 'Wirz Werbung' from 1999 until 2005 and were found on the internet, where they are easily accessible.

The verbal and visual structure of the advertising campaign, in terms of spatial composition, is simple. A typical advertisement of the IWC campaign is built up by a provocative claim that catches the attention and takes up half of the advertisement's space. Then, in a very small font compared to the claim, follows the body copy with the general details of the watch, and finally the verbal code, which is made up by the brand's name and the slogan. The visual code is just the illustration of the watch in large-format, taking up about a half of the advertisement. The colours of the advertisements are black and white. The design of the campaign is minimalistic, the eye catching-effect can be found, without a doubt, in the provocative and shock-intending claims.

\section{Equality of the sexes has to stop somewhere.}

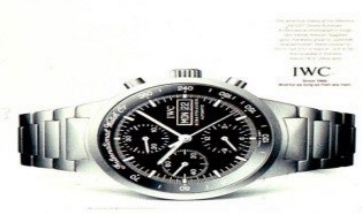

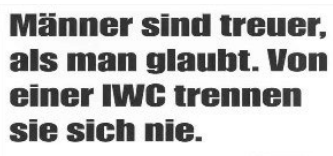

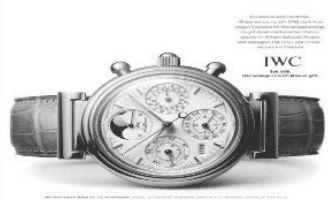

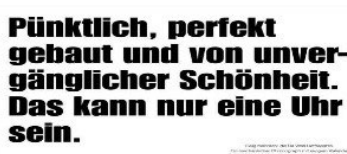

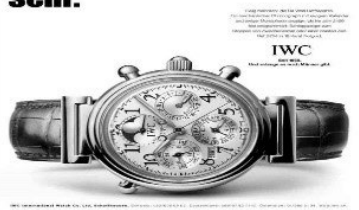

Fig. 1: Advertisements of the IWC-campaign

The analytical framework for the analysis is the feminist critical discourse analysis (FCDA), developed by Lazar $(2005,2007)$. By applying this analytical method, the complex workings of power and ideology in discourse in maintaining hierarchical gendered social order can be analysed. FCDA seeks to examine «the complex, subtle, and sometimes not so subtle, ways in which frequently taken-for-granted gendered assumptions and hegemonic power 
relations are discursively produced, sustained, negotiated, and challenged in different contexts and communities» (Lazar, 2007, p. 142). The approach also acknowledges multimodality of different semiotic codes for a holistic analysis of meaning-making practices. Lazar $(2005,2007)$ views a feminist critical discourse analysis as a political praxis articulated around five interrelated principles based on gender, power and ideology: (a) feminist analytical resistance/activism, (b) gender as ideological structure and practice, (c) complexity of gender and power relations, (d) discourse in the (de)construction of gender, and (e) critical reflexivity as praxis. The first one seeks to make sense of how social practices are discursively constructed, whereas the second conceptualises gender as an ideological construct that upholds existing ideas and/or power relations. The third principle shows that gender and power relationships in current society are complex and intersectional. The fourth one focuses on how gender ideology and gendered relationships of power are (re)produced, negotiated and represented in social practices. And the last tenet encompasses a broader reflection on the construction of gender.

This is considered to be a suitable framework for the current study, as FCDA enables an analysis of discursive strategies of unequal gender structures and the representation of demeaning stereotypes and the construction of a retro-sexist world. Inspired by the principles established by the FCDA, the practical analysis undertaken in this study intends to respond to the questions of how the IWC advertising campaign (a) deals with gender as an ideological structure, (b) presents complex power relations, (c) (de)constructs gender in the advertising discourse, and, finally, (d) finishes with a critical reflexivity of the advertising discourse praxis. It is our hypothesis that there is little humour or irony in this campaign, instead it ridicules gender equality and constructs a retro-sexist imagery, by making fun of feminist gains and conveying out-dated gender clichés, which leads to the stereotyping of women's characters and attitudes in a demeaning way. With the aim of showing how asymmetrical gender relations are (de)constructed in the IWC advertising campaign, the analytical procedure intends to examine how gender norms are reproduced in the advertisements. On the one hand, stereotypes about male and female physical appearance, personality traits, role behaviours and occupations are detected. On the other hand, retro-sexual gender clichés are interpreted. The results uncover discourse

Feminismo/s 38, July 2021, 177-202 
strategies expressing reverse oppression, from female to male, and rejection of postfeminist assumptions.

\subsection{Representation of retro-sexist gender portrayal}

The discursive world that is created by the advertising campaign is a sort of IWC-universe conveying a retro-sexist imagery within heteronormativity based on binary gender relations, in which men can be men with all the privileges they had before the 'bad' feminism took them away. Men, in this imagery, have become a sort of victim of a female-dominated world, presupposing women have gained it all: equal rights and occupations outside the domestic sphere. Inside the IWC-universe men are protected by the brand, it is outside of it where men are oppressed by a sort of female world order. The IWC-universe seeks to stereotype women in their physical appearance, personality traits and gender roles, conveying demeaning gender clichés. Hence, a retro-sexist imagery is constructed, where the gender structure is based on male power and oppressive mechanisms.

In what follows, illustrative claims are selected to explain how the IWCuniverse gets rid of the female-dominated gender structures in the advertising world taking postfeminist discourse as a starting point. Four strategies represent gender portrayal to construct a retro-sexist imagery: (a) reversal of power relations, (b) heterosexual relationship, (c) gender stereotypes and (d) biological and psychological gender dissimilarities.

\subsubsection{Reversal of power relations}

The campaign harshly attacks feminist assumptions as it is based on the idea that feminism has gone too far and that women, in their conviction to 'have it all ', are all out to take over. The time will come, according to the slogan, that appears in all advertisements, when men as a species will die out, because of female emancipation and liberation.

(1) Since 1868. And as long as there are men.

Seit 1868. Und solange es noch Männer gibt.

A world is painted where power relations have become reversed: it is women who wield power and control over men. Men are totally subjugated by women. 
The brand IWC becomes the symbol of empowerment for men living under feminist oppression. Power relations between women and men are shifting in favour of women, but the watch IWC is able to return the IWC-man into a pre-feminist stage, where gender relations are unequal and men enjoy all sorts of privileges.

(2) Equality has to stop somewhere.

Irgendwo hört die Gleichberechtigung auf. Hier.

The claim suggests that there is actually gender equality, but this is just true inside the limited IWC-advertising world, in real life this statement is not valid, as there are still many issues that have to be resolved in order to reach full gender equality.

Men are presented as victims that suffer oppression by claiming that they are a minority. It is very persuasive, as the brand itself with the personal pronoun 'we' is speaking to men. As a group they are encouraged, by addressing them directly with an imperative, to proclaim themselves to be real men without feeling ashamed of it.

(3) Wir machen Uhren für eine Minderheit. Männner.

(4) Outen Sie sich als Mann.

Men have lost everything in the struggle of the sexes. Only the IWC watch remains faithfully at their side and makes them feel strong. Women are addressed directly in a harsh way and given orders not to take away the IWC-watch, the only object men preserve, as it is the only survivor in the feminist struggle.

(5) Ladies, you ride our Harleys, smoke our Havanas, drink our Glenmorangie. Hands off our IWC.

The brand IWC restores men's dignity with a rhetoric question and a word pun in German, referring to male domination in the domestic sphere. In the male-dominated IWC-universe men dominate over women and no feminist will stop that.

(6) Wer hat bei Ihnen zu Hause die IWC an?

(7) Our titanium model is tough on women, because it's only available for men. 


\subsubsection{Heterosexual relationship}

A characteristic feature of the IWC advertising campaign is the narrative about heterosexual relationship and marriage. Women in their role as wives are undermined and held in low regard.

(8) Lassen Sie Ihre Frau die Kiste Bier tragen, Ihre Uhr ist ja schwer genug.

(9) Ein erfogreicher Mann ist, wer sich etwas mehr leisten kann, als ihn seine Frau kostet.

IWC becomes a fabulous adviser in heterosexual relationships, as it even recommends the separation of property as the best legal form of living together as a married couple.

(10) IWC empfiehlt Gütertrennung.

Divorce becomes hard because of greedy wives who cause economic ruin of their husbands. On the other side, men might be unfaithful to their wives but never to their IWC watch, as men deserve a better life than their wives are willing to give them.

(11) Sie kann das Haus haben. Den Wagen. Den Hund. Aber niemals meine IWC.

(12) How faithful are men? We've never known one to leave his IWC.

(13) Männer verdienen mehr als Frauen. Zum Beispiel eine IWC.

By conveying men can fully trust the IWC brand, it implies women are not trustworthy as they cheat on men in the relationship.

(14) Immerhin etwas, worauf sich Männer verlassen können.

(15) Männer tragen ihr Geweih am Handgelenk.

\subsubsection{Gender stereotypes}

The IWC advertising campaign creates an imagery where men gain back their supremacy over women by overtly defending a patriarchal gender order. By doing so, empowerment of men is presented vis-à-vis the disempowerment of women. This can clearly be observed in the gender stereotypes about physical appearance and personal traits. Men are presented as attractive even if they have gained weight or if they have grown older. Underlying is the 
assumption that fat and aged women are not at all attractive and seductive. This is emphasized by the comparative 'as a man', implying the idea 'not as a woman'.

(16) Ein paar Gramm mehr steht allen Männern gut.

(17) Funktioniert bis ins hohe Alter. Wie ein Mann.

(18) Hart im Nehmen und mit zunehmendem Alter attraktiver. Wie ein Mann.

Women might be beautiful and decorative, and men have to pay a high monetary price. This claim implies that women can be purchased like an object. On the other hand, women do not behave appropriately towards men. The IWC watch instead is beautiful and works always to men's satisfaction.

(19) Fast so schön wie eine Frau. Kostet aber nur einmal Geld.

(20) Pünktlich, perfekt gebaut und von unvergänglicher Schönheit. Das kann nur eine Uhr sein.

One of the vast extended stereotypes is that women are unpunctual and always arrive late when having a date. Another negative personal trait about women is expressed: their complicated and unpredictable character that gives men a hard time. Instead, the IWC watch is complicated because of its machinery.

(21) Almost as complicated as a woman. Except it's on time.

When referring to gender roles, women are presented in traditional roles where they are portrayed as housewives that keep the house clean and care for the children, while their husbands earn money. Men are not made for domestic chores - instead, women should do that less qualified work.

(22) Viel zu schade zum Einkaufen. Waschen, Putzen und Wickeln.

(23) Scheiben putzen ist Männersache. Bis $42 \mathrm{~mm}$ Durchmesser.

Men are portrayed in a profession that requires leading qualities, while women working outside the home are portrayed in the typical female profession of stewardess. It is part of a male erotic dream having an affair with a stewardess.

(24) Männer, die in Kniestrümpfen arbeiten müssen, haben eine Belohnung verdient.

(25) Often seen in stewardesses' bedside tables. 
But the IWC advertising campaign also makes allusions to the 'new' role of men portrayed in domestic labours and caring for children. But men's involvement in family life is reduced without being an active part in the household.

(26) Mit dieser Uhr können Sie die Kochzeit von zwei verschiedenen Frühstückseiern stoppen. Und das direkt im Topf.

(27) Ein Geschenk für die ganze Familie: ein glücklicher Vater

\subsubsection{Biological and psychological gender dissimilarities}

The advertising campaign refers also to biological and psychological differences between women and men. Men's biological traits are always positive.

(28) Männliches Erbgut.

(29) Aus unserer Testosteron-Produktion.

(30) Das beste Stück des Mannes misst 500 Jahre.

Women's biological traits, as their hormons and irritating voice, are annoying to men.

(31) Bringt den Hormon-Haushalt durcheinander. Den weiblichen.

(32) Endlich ein Navigationssystem ohne nervige Stimme.

By directly addressing men and women, the brand and the IWC-men build up a close friendship and they even become allies against women and wives.

(33) Kostet genau soviel, wie Sie für den Wagen Ihrer Frau bekommen.

(34) Keine Panik, Frauen. Euer IWC-Neid ist etwas völlig Normales.

(35) Falls Sie immer noch nicht wissen, was an einem richtigen Mann so dran ist.

There is a total exclusion of women from the IWC-universe, where only men belong to because they possess the required biological qualities.

(36) Für alle, die sich rasieren. Im Gesicht.

(37) Passt auch zu Röcken. In Schottland.

(38) Erhältlich ab Schuhgrösse 43

\subsection{Construction of a retro-sexist imagery}

The central message of the advertising campaign IWC lies in the assumption that it is the brand that rescues men from a female-dominated world, and 
gives back the pride of being a man, that has been destroyed by the feminist movement. An imagery is created in which men have become henpecked husbands at home dominated by strong-willed women. The brand becomes the only ally to liberate men from a hierarchical oppressive female-dominated world.

Men are portrayed in the campaign from a highly masculine perspective, holding up traditional gender stereotypes forcing them into confined roles and expecting them to behave according to the masculine ideal, thus, supporting a very traditional gender norm that does not tie in with the real advances masculinity has undergone. Women are depicted as unpunctual, as having a complicated and unstable personality, as being expensive for men who have to spend a lot of money on them, and as financially ruining them when getting divorced. The IWC-universe gives men simple and straightforward ideas and solutions on how to break out of the deplorable situation of being a subjugated man. It creates a world where modern men can escape from being a victim of feminism and postfeminism.

Postfeminist assumptions are the starting point in the IWC-advertising discourse, as (a) women are seen as powerful and emotionally and economically independent, (b) gender orders have switched and power relations have become reversed, and (c) men have become the new subordinated group and are victims of a female-dominated world. Hence, advertising discourse strategy is based on the appropriation of postfeminist standpoints, with the purpose of reverting this gender asymmetry in favour of women and restore the existing gender asymmetries before the feminist era. To fulfil this purpose, a retro-sexist imagery is created. By doing so, masculinity is reinforced in an exaggerated manner at the expense of undermining femininity. Gender stereotypes and clichés are employed in a way in which male stereotypes are without exception positive while demeaning female stereotypes are frequent.

Some of the claims might be catalogued as humorous as they show a creative usage of language. By using puns, as can be seen in examples (6), (15), (30) and (35), the advertising campaign seems to make fun of gendered misconceptions and existing patriarchal structures. But the humorous elements only work if one assumes that the addressees share the same kind of humour as IWC. Surely, humour is a culture-embedded subject and a translation of the IWC-claims would fail to function cross-culturally. In Eastern cultures,

Feminismo/s 38, July 2021, 177-202 
like China and Japan, and even in the USA, this cutting-edge advertising campaign would not work, as it is not a suitable campaign for a global advertising strategy (Lüchinger, 2005; Weber, 2002). That is why, after six years it was replaced by a more cross-culturally compatible campaign designed by a new advertising agency. Nevertheless, it has been exhibited for a long time and the vast amount of material (around 1000 posters), undoubtedly, contributed to the perpetuation of demeaning stereotypical and retro-sexist images of women, as «prolonged experience of advertising and other commercial texts contributes to shaping people's identities as 'consumers', or their gender identities» (Fairclough, 2003, p. 8).

\section{FINAL REMARKS}

The study presented reflects on the misuse and appropriation of feminist standpoints by advertising discourse. The starting point in this kind of discourse is a fictitious gender asymmetry in favour of women, in which gender roles are reversed and gender equality has to be cancelled. In the first part of the article, feminist waves and postfeminism, as well as gendered stereotypical portraying in advertising were outlined. In the second part, a case study was carried out, applying a feminist critical discourse analysis to show the effectiveness of a cutting-edge advertising discourse which was based on reinforcing masculinity by degrading women employing demeaning female gender stereotypes and clichés. It critically examined the advertising campaign of the Swiss brand IWC, a luxury brand that produces high quality and high-priced watches. Four strategies within a feminist critical discourse analysis approach were identified to represent gender portrayal and to construct a retro-sexist imagery: (a) reversal of power relations, (b) heterosexual relationship, (c) gender stereotypes and (d) biological and psychological gender dissimilarities

The IWC-campaign is an example of how advertising, by overtly transmitting retro-sexist and demeaning messages works against women, misuses its power, working against gender equality. The advertising agency 'Wirz' declared after finishing the campaign that «Die Kampagne war niemals frauenfeindlich, aber immer männerfreundlich gemeint» [translated: the campaign was never intended to be hostile towards women but always pleasing 
to men] (Wirz ohne IWC Uhren, 2005). Our study has shown the contrary. The feminist critical discourse analysis undertaken has brought the following conclusions:

The IWC advertising campaign stands for an advertising strategy that follows postfeminist assumptions, as it stresses that women's powerlessness and patriarchal oppression are outdated. And it is this standpoint that produces a cutting-edge advertising discourse with the intention of getting back to a pre-feminist stage, when the gendered social orders were hierarchical and male-dominant. By doing so, all sorts of female stereotypes about physical appearance, personal traits and gender roles are mentioned, some of them being demeaning and destructive for postfeminist women who believe in equal gender structures. Gender stereotypes and clichés are presented asymmetrically, while for women they are negative for men they are positive. The IWC campaign creates an imagery that is retro-sexist for both genders, although the way in which women and men are portrayed does not correspond to reality. There is not such power reversal, where women control gender power relations and men form a subordinated group or even a minority. It is not a fast becoming women's world, where women have gained gender equality. This assumption hardly matches the world outside of the advertising universe. Thus, retro-sexist as well as sexist advertising has a highly damaging effect on equal gender relations and gender equality. In this kind of advertising, the conception of gender as a social construct is ignored, instead the strength of the male sex is reinforced. Gender equality becomes the battlefield where male power struggles against the female sex. Social gender asymmetries are not regarded in terms of gender conflict that should be solved, but in terms of struggle of sexes based on biological strength, where men are the winning team.

Generally, advertising picks up on and reflects, like a mirror, existing sexist gender clichés. The success of the IWC campaign in German-speaking countries shows that there exists an underlying wishing back of retro-sexist gender structures. This can also be interpreted in terms of a backlash for postfeminism, as «postfeminist discourse in a way encourages a new kind of anti-feminist sentiment that attempts to thwart the re-emergence of feminist political critique» (Lazar, 2014, p. 223). 
Advertising campaigns with sexist, retro-sexist and stereotypical messages cannot be catalogued as amusing and even humorous. It is my contention that advertising within media discourse plays a leading role in the perpetuation of gender stereotypes, especially those that are exploitative and stereotypical images of women, and it reinforces disfigured gender relations in the collective imagery. This kind of advertising contributes little to settle the unequal status quo and, for sure, does not encourage progress towards effective gender equality and, thus, social justice.

\section{REFERENCES}

Akestam, N., Resengren, S., \& Dahlen, M. (2017). Advertising 'like a girl': Toward a better understanding of 'femvertising' and its effects. Psychology and Marketing, 34, 795-806. https://doi.org/10.1002/mar.21023

Arend, P. (2014). Gender and Advertising. In P. Leavy \& A. Trier-Bieniek (Eds.), Gender \& Pop Culture: A Text-Reader. (pp. 53-79). Sense Publishers. https:// doi.org/10.1007/978-94-6209-575-5_3

Catterall, M., Maclaran, P., \& Stevens, L. (2005). Postmodern Paralysis: The Critical Impass In Feminist Perspectives on Consumers. Journal of Marketing Management, 21, 489-504. https://doi.org/10.1362/0267257054307444

Eisend, M., Plagemann, J., \& Sollwedel, J. (2014). Gender Roles and Humor in Advertising: The Occurrence of Stereotyping in Humorous and Nonhumorous Advertising and Its Consequences for Advertising Effectiveness. Journal of Advertising, 43(3), 256-273. https://doi.org/10.1080/00913367.2013.857621

Eisend, M. (2019). Gender Roles. Journal of Advertising, 48, 72-80. https://doi. org/10.1080/00913367.2019.1566103

Fairclough, N. (2003). Analysing discourse: textual analysis for social research. Routledge. https://doi.org/10.4324/9780203697078

Furnham, A., \& Paltzer, S. (2010). The portrayal of men and women in television advertisements: an update review of 30 studies published since 2000. Scandinavian Journal of Psychology, 51(3), 216-236. https://doi. org/10.1111/j.1467-9450.2009.00772.x

Gentry, J., \& Harrison, R. (2010). Is advertising a barrier to male movement toward a gender change? Marketing Theory, 10(1), 74-96. https://doi. org/10.1177/1470593109355246 
Gill, R., \& Arthurs, J. (2006). Editors' Introduction. Feminist Media Studies, 6(4), 443-451. https://doi.org/10.1080/14680770600989855

Gill, R. (2016). Post-post feminism? new feminist visibilities in postfeminist times. Feminist Media Studies, 16(4), 610-630. https://doi.org/10.1080/1468 0777.2016 .1193293

Grau, S. L., \& Zotos, Y. C. (2016). Gender stereotypes in advertising: a review of current research. International Journal of Advertising, 35(5), 761-770. https:// doi.org/10.1080/02650487.2016.1203556

IWC Homepage. Retrieved February 25, 2021, from https://www.iwc.com/en/ home.html

IWC wechselt zu JvM/Alster (2005, March 17). Die Werbewoche. Retrieved February 25, 2021, from https://www.werbewoche.ch/de/werbung/2005-03-17/ iwc-wechselt-zu-jvm-alster/

IWC-Werbung wirkt (2015, January 28). 100 Percent Passion. Retrieved February 25, 2021, from https://100percentpassion.net/2015/01/28/ iwc-werbung-wirkt/

Jaffe, D., \& Riedel, S. (2011). Werbung für Adam und Eva. Zielgruppengerechte Ansprache durch Gender Marketing Communication. WILEY-VCH Verlag.

Kreienkamp, E. (2007). Gender-Marketing. Impulse für die Marktforschung, Produkte, Werbung und Personalentwicklung. Mi-Fachverlag.

Lazar, M. M. (2005). Politicizing Gender in Discourse: Feminist Critical Discourse Analysis as Political Perspective and Praxis. In M.M. Lazar (Ed.), Feminist Critical Discourse Analysis: Gender, power and ideology in discourse (pp. 1-29). Cambridge University Press. https://doi.org/10.1057/9780230599901_1

Lazar, M.M. (2006). Discover the power femininity! Analyzing global 'power femininity' in local advertising. Feminist Media Studies, 6(4), 505-517. https:// doi.org/10.1080/14680770600990002

Lazar, M.M. (2007). Feminist Critical Discourse Analysis. Articulating a feminist discourse practice. Critical Discourse Studies, 4(2), 141-164. https://doi. org/10.1080/17405900701464816

Lazar, M.M. (2014). Recuperating feminism, reclaiming femininity: hybrid postfeminist I-dentity in consumer advertisements. Gender and Language, 8(2), 205-224. https://doi.org/10.1558/genl.v8i2.205

Lewis, P., Benschop, Y., \& Simpson, R. (2017). Post feminism, Gender, and Organization. Gender, Work, and Organization, 24(3), 213-225. https://doi. org/10.1111/gwao.12175

Feminismo/s 38, July 2021, 177-202 
Lüchinger, R. (2005, March 22). IWC Schluss mit Machismo. Handelszeitung. Maclaran, P. (2012). Marketing and feminism in historic perspective. Journal of Historical Research in Marketing, 4(3), 462-469. https://doi. org/10.1108/17557501211252998

Maclaran, P. (2015). Feminism's fourth wave: a research agenda for marketing and consumer research. Journal of Marketing Management, 31(15-16), 17321738. https://doi.org/10.1080/0267257X.2015.1076497

Mayer, J. M., Kumar, P., \& Yoon, H. J. (2019). Does sexual humour work on mars, but not on Venus? An exploration of consumer acceptance of sexually humorous advertising. International Journal of Advertising, 38(7), 1000-1024. https://doi.org/10.1080/02650487.2019.1629226

McRobbie, A. (2009). The Aftermath of Feminism. Sage.

McRobbie, A. (2015). Notes on the Perfect. Australian Feminist Studies, 30(83), 3-20. https://doi.org/10.1080/08164649.2015.1011485

Mills, S. (1995). Feminist Stylistics. Routledge.

Petersson McIntyr, M. (2020). Agencing femininity: digital Mrs. Consumer in intra-action. Journal of Cultural Economy, 13(1), 54-72. https://doi.org/10.10 80/17530350.2019.1639529

Plakoyiannaki, E., \& Zotos, Y. C. (2009): Female role stereotypes in print advertising. Identifying associations with magazine and product categories. European Journal of Marketing, 43(11/12), 1411-1434. https://doi. org/10.1108/03090560910989966

Rome, A.S., O'Donohoe, S., \& Dumnett, S. (2019). Rethinking feminist waves. In S. Dobscha (Ed.), Handbook of research on Gender and Marketing (pp. 252271). Edward Elgar Publishing. https://doi.org/10.4337/9781788115384.00016 Scott, L.M. (2000). Market feminism: the case or a paradigm shift. In M. Catterall, P. Maclaran, \& L. Stevens (Eds.), Marketing and Feminism: current Issues and Research (pp. 16-38). Routledge..

Scott, L.M. (2005). Fresh Lipstick: Redressing Fashion and Feminism. Palgrave. Tannen, D. (1995). You just don't understand: women and men in conversation. Virago.

Uhrenwerbung im Stillstand (2001, March 22). Die Werbewoche. Retrieved February 25, 2021, from https://www.werbewoche.ch/de/werbung/2001-03-22/ uhrenwerbung-im-stillstand/

Weber, L. (2002, February 3). IWC Werbung zwischen Machismo und Globalisierung. Für letzte Mohikaner. Neue Züricher Zeitung. 
Williamson, J. (2003, May 31). Sexism with an alibi. The Guardian, 1-3.

Windels, K., Champlin, S., Summer, S., Sterbenk, Y., \& Poteet, M. (2019). Selling Feminism: How female empowerment campaigns employ postfeminist discourses. Journal of Advertising, 49, 18-33. https://doi.org/10.1080/00913367 .2019 .1681035

Wirz ohne IWC Uhren - «Jetzt sind wir unser Macho-Image los» (2005, June 9). DerStandard. Retrieved February 25, 2021, from https://www.derstandard. at/story/1994512/wirz-ohne-iwc-uhren-jetzt-sind-wir-unser-macho-image

Zawisza, M. (2019). Gendered Advertising: content, effectiveness and effects - psychological perspective. In S. Dobscha (Ed.), Handbook of research on gender and marketing (pp. 8-27). Edward Elgar Publishing. https://doi. org/10.4337/9781788115384.00006 